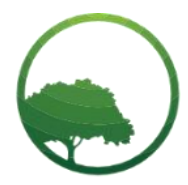

Research in Business \& Social Science

IJRBS VOL 9 NO 3 ISSN: 2147-4478

\title{
Application of Basel III on health level in banking sub sector company
}

\author{
Yutaka Erwan $\oplus_{(a)}$, John Henry Wijaya@(b) \\ $(a, b)$ Faculty of Business and Management, Widyatama University, Bandung, Indonesia
}

Crossref

\begin{tabular}{l} 
A R T I C L E I N F O \\
\hline Article history: \\
Received 28 February 20 \\
Received in revised form 05 March 20 \\
Accepted 12 March 20 \\
\hline Keywords: \\
Liquidity coverage ratio, Altman \\
Modifikasi, Grover, Basel III, \\
regression analysis \\
JEL Classification: \\
O15, P36
\end{tabular}

\begin{abstract}
A B S T R A C T
The purpose of this study is to determine the effect of the level of banking health on the ratio of liquidity coverage in the corporate banking sub-sector included in the category of commercial banks based on business activities (BOOK) 3 during the 2017-2018 period with each period only taking 2 quarterly data. The sample in this study was a banking company listed on the IDX and included in a commercial bank based on business activities (BOOK) 3 consisting of 19 banks selected using the purposive sampling method, with a total of 76 data units. The analytical method used in this study is panel data regression analysis. The results of partial hypothesis testing indicate that the ratio of liquidity coverage is influenced by the level of health with the Altman Z-Score modification method and the Grover GScore method.
\end{abstract}

(C) 2020 by the authors. Licensee SSBFNET, Istanbul, Turkey. This article is an open access article distributed under the terms and conditions of the Creative Commons Attribution (CC BY) license (http://creativecommons.org/licenses/by/4.0/).

\section{Introduction}

In achieving development and economic growth in Indonesia, it takes the role of banks as institutions that support the economy. The bank is an institution that carries out activities to collect funds from parties who have more funds (surplus spending units) and channel them back to those who need funds (deficit spending units) that will improve the welfare of the public (Raz, 2013, Shahbaz et al, 2013, Supartoyo et al, 2013; Kurniawan and Managi, 2018). In the law, banks have 3 (three) main functions, namely, receiving deposit funds, channeling funds, and performing other financial services (Banking Law No. 10, 1998). Based on these definitions and functions, it can be said that the bank is one of the financial institutions that carries out an intermediary function for funds received by customers.

The performance of individual banks and the banking system is reflected in the behavior of banks in managing assets as the use of funds and liabilities as a source of funds. In summary, it can be explained that the bank balance sheet is divided into 2 parts, namely asset position and liability position. From the source and use of funds there is usually a difference or gap. If the source of funds is greater than the use of funds, it is called a positive gap. Conversely, if the source of funds is smaller than the use of funds is called a negative gap. If the source of funds and use of funds have the same amount then it is called a zero gap.

Profitability is one of the right indicators to measure the performance of a bank. The ability of banks to find sources of funds to finance their activities is illustrated by the soundness of the bank. In principle, Basel III policy aims to improve the ability of the banking sector to absorb potential loss risk.

This study aims to determine the effect of the level of banking health on the ratio of liquidity coverage in the corporate banking subsector included in the category of commercial banks based on business activities (BOOK) 3 during the 2017-2018 period with each period only taking 2 quarterly data.

* Corresponding author. ORCID ID: 0000-0001-6970-9104

(C) 2020 by the authors. Hosting by SSBFNET. Peer review under responsibility of Center for Strategic Studies in Business and Finance. https://doi.org/10.20525/ijrbs.v9i3.688 
The sample in this study was a banking company listed on the IDX and included in a commercial bank based on business activities (BOOK) 3 consisting of 19 banks selected using the purporsive sampling method, with a total of 76 data units. The analytical method used in this study is panel data regression analysis.

The reminder of this study is organized as follows. The next section provides a review of extant literature. The third section introduces methodology and data. Finally, conclusions and implications of the study are presented in the final section.

\section{Literature Review}

\section{Background of the Study}

Asset and liability management has the objective to obtain profits and increase the value of the company / bank with sufficient liquidity, sufficient capital, and low risk. Therefore, in order to achieve a condition where assets can generate greater income than costs incurred, a good gap management needs to be maintained in order to maintain a certain level of net income and can be increased. Thus, banks will extend credit in order to achieve this by optimizing credit portfolios in accordance with the maximum limits per sector and capital adequacy.

The banking sector will still be the belle sector for most investors, this is because banking will always be needed by the entire capital market as an intermediary institution. Even in 2017, the financial services sector index recorded an increase of $41 \%$, the highest compared to nine other stock sector indexes. Significant performance from this sector index was supported by strengthening banking shares. The banking fundamental performance was driven by the positive performance of issuers in this sector. In October 2017, the current year's profit before Indonesian banking tax recorded an increase of 14.5\% YoY, higher than the achievement of the same period the previous year which was $11.5 \%$ YoY. This continued until early 2018 when the banking sector became very good for foreign investors. Even banking stocks always go into the top 5 stocks collected by foreign investors every day. Improved performance will be a fundamental question whether the banking sector will be immune to bankruptcy? Add to this the new policy on Liquidity Coverage Ratio (LCR) which was produced as a banking revival after the Basel III crisis, where in Indonesia this policy has been applied in all banks in the BOOK 3 and BOOK 4 categories from 2015 to the present, although the results are still not good, evidenced by the high ratio of loans to deposits (LDR), as in the Table 1.

Table 1: Loan to deposit (LDR) level and conventional bank liquid assets ratio level

\begin{tabular}{|c|c|c|c|c|c|}
\hline \multirow[t]{2}{*}{ Year } & \multicolumn{4}{|l|}{ Bank } & \multirow[t]{2}{*}{ Liquid Assets Ratio Level } \\
\hline & BOOK 1 & BOOK 2 & BOOK 3 & BOOK 4 & \\
\hline 2015 & 86.04 & 97.81 & 99.37 & 85.63 & 16.7 \\
\hline 2016 & 94.23 & 98.04 & 95.96 & 85.16 & 17.5 \\
\hline 2017 & 89.09 & 91.22 & 96.63 & 85.96 & 18.56 \\
\hline 2018 & 92.27 & 94.03 & 103.37 & 89.90 & 14.96 \\
\hline
\end{tabular}

The increase in the level of LDR is also followed by a decrease in the ratio of liquid assets which is a comparison between the amount of primary and secondary liquid assets to total assets, the level of LDR which tends to be high and the average level. the ratio of liquid assets that did not increase significantly and showed a drastic decline in 2018, shows that until now, the existing liquidity ratios still indicate that liquidity risk in banks as financial institutions is in an insecure and high risk position. In this condition, conventional banks in commercial banks based on the category of business activities (BOOK) 3 have the highest liquidity risk, because the level of LDR is high when compared to conventional banks in the BOOK 4 category.

Conditions faced like this are not only experienced by Indonesia, Jamaica even plans to introduce new Liquidity Coverage Ratio (LCR) in 2019 in anticipation of their country's banking sector, which until now is still in a state of recovery, which is expected to be in accordance with IMF directives can provide significant results for the economy of the country (Jamaica, 2019).

Australia even took 3 years to be able to meet the provisions in the Liquidity Coverage Ratio (LCR), first introduced on 1 January 2015 by the Australian Prudential Regulation Authority (APRA) with an initial minimum LCR requirement of only 60\%, where the following year increased by $10 \%$ so that in 2019 it can reach what is required by $100 \%$. This is with the consideration that Authorized deposit-taking institutions that guarantee the deposits of customers are able to meet the amount of deposits greater than the use of external funds. The implementation of LCR in Australia is supported by the implementation of the Net Stable Funding Ratio requirements on January 1, 2018 (Grummit, 2013).

Referring to research conducted in the European region, that liquidity tools are special but cannot completely remove the need for Lender of Last Resort (LOLR) interventions by the central bank. Full compliance with current Liquidity Coverage Ratio (LCR) and Net Stable Funding Ratio (NSFR) rules would have reduced banks' reliance on publicly provided liquidity during the global financial 
crisis without removing such assistance altogether. This result is more or less the same as the application in Australia (Hoerova et al, 2018).

The application of Liquidity Coverage Ratio (LCR) in Hong Kong also shows that the application takes time to be properly applied, the Hong Kong Monetary Authority as the highest banking institution in Hong Kong has decided that the application of Liquidity Coverage Ratio (LCR) is exactly the same as Australia, which was implemented starting January 12015 with a minimum requirement of only $60 \%$ with the following year increasing by $10 \%$ so that on January 1, 2019 will be in accordance with the general requirements of $100 \%$ (Authority, 2013).

This indicates that the application of Liquidity Coverage Ratio (LCR) for banks included in BOOK 3 and BOOK 4 is at least $100 \%$ in accordance with the Financial Services Authority regulation Number 42 / POJK.03 / 2015 for the next 30 days in a stress scenario, not yet guarantee a banking institution will be free from stress (bankrupt). Therefore, this study would like to explore further how the influence of the level of banking health as measured by the Altman z score modification and Grover on the application of Liquidity Coverage Ratio in banking institutions included in BOOK 3 during the 2017-2018 period with quarterly times in each that year.

Based on this background, several problems can be formulated as follows:

1. How does the level of health influence by the Altman Z-Score Modification method on the regulation of Liquidity Coverage Ratio.

2. How does the level of health influence by the Grover method on the regulation of Liquidity Coverage Ratio.

Besides Liquidity Coverage Ratio (LCR) and Net Stable Funding Ratio (NSFR), there are two more ratios that can be used to evaluate the health condition of a bank, namely Capital Adequacy Ratio (CAR) and Loan to Deposit Ratio (LDR). According to (Hermina \& Suprianto, 2014) Liquidity Coverage Ratio (CAR) is a capital ratio that shows the ability of banks to provide funds for business development needs and accommodate the risk of loss of funds caused by bank operations. Liquidity Coverage Ratio (CAR) shows the extent to which a decline in bank assets can still be covered by available bank equity. The higher the value of the Liquidity Coverage Ratio (CAR), the more capital owned by the bank to cover the decline in assets. Whereas the Loan to Deposit Ratio (LDR) shows the amount of credit granted financed with third party funds. In addition, this ratio is used to measure the level of the bank's ability to pay third party funds from the return of loans given from the interest charged to depositors (assuming there is no bad credit).

The sample in this study are banking companies listed on the IDX and included in commercial banks based on business activities (BOOK) 3 consisting of 19 banks selected using the purporsive sampling method, with a total of 76 data units. The analytical method used in this study is panel data regression analysis.

From the phenomenon and the relationship between theory, this research is very important to do. Based on these reviews, researchers are interested in conducting a study entitled "Basel III Application of Soundness in Banking Sector Companies",

\section{Theoretical background}

\section{Altman Z-Score Model}

According to Altman and Hotchkiss (2006), the Altman method is a method of predicting soundness which is the result of a combination of information and data from various financial statements and measurement of market values, which then produces a valuation method to classify an observed company, whether it is in the condition of the level health or not in a state of health. The new Altman Z-Score model, the Emerging Market (EM) Score or commonly referred to as the Altman Z-Score Modification has the following formula:

$\mathrm{Z}=6.56 \mathrm{X}_{1}+3.6 \mathrm{X}_{2}+6.2 \mathrm{X}_{3}+1.05 \mathrm{X}_{4}$

In this Modified Altman Z-Score model, the cutoff is used for classification of calculation results where if the value of "Z" $<1.1$ then the company is categorized as in a state of soundness, whereas if the value of " $Z$ " is in the condition of $1.1<" Z$ " $<2.6$, the company is categorized in the gray area, or not in the condition of soundness or in a healthy condition and if the value of" $\mathrm{Z}$ "> 2.6, the company is categorized in a healthy condition.

\section{Grover model}

The Grover Model is a model created by designing and re-evaluating the Altman Z-Score model, where the originator, Jeffrey S. Grover, used a sample in accordance with the Altman Z-Score model in 1968, adding 13 (thirteen) new financial ratios. Grover used a sample of 70 companies with 35 companies going bankrupt and 35 companies not going bankrupt in 1982 to 1992 , and then produced the following model:

$\mathrm{G}=1.650 \mathrm{X}_{1}+3.404 \mathrm{X}_{2}-0.016 \mathrm{ROA}+0,057$

In this Grover G-Score model, the cutoff is used for classification of calculation results where if the value of "G" $\leq-0.02$ the company is categorized as in a state of soundness and if the value of "G" $\geq 0.01$ then the company is categorized as not in health condition (Edi and Tania, 2018). 


\section{Liquidity coverage ratio}

Based on the Financial Services Authority Regulation Number 42 / POJK.03 / 2015 Regarding the Obligation to Meet the Liquidity Coverage Ratio for Commercial Banks, it is defined that the Liquidity Coverage Ratio (LCR) is a comparison between High Quality Liquid Asset (HQLA) with total cash flow net outflow for the next 30 (three recovered) days in a stress scenario. In the same regulation, HQLA is defined as cash and / or financial assets that can be easily converted into cash with little or no reduction in value to meet the Bank's liquidity needs for the next 30 (thirty) days in the stress scenario. Whereas the Total Net Cash Outflow, or Net Cash Outflow (NCO), is the total estimated cash outflow minus the estimated total cash inflows expected to occur during the next 30 (thirty) days in the stress scenario, with the following model (Duijm and Wierts, 2016)

Liquidity Coverage Ratio $=\frac{\text { High Quality Liquid Asset }}{\text { Net Cash Outflow }}$

There are several conditions that are required in the LCR regulations issued by the FSA listed in Articles 1, 2, and 3, including:

1. The bank meets the adequacy of liquidity calculated by LCR with the lowest fulfillment of $100 \%$ on an ongoing basis.

2. Banks are required to inform OJK about the condition of bank liquidity in terms of being unable or potentially unable to meet LCR up to $100 \%$, and in this condition banks are required to analyze the condition of bank liquidity including reasons or causes, steps to improve liquidity conditions, and the period of liquidity stress estimated by the bank, to then be reported to OJK.

OJK regulations also regulate banks which are required to comply with LCR regulations, as stated in Articles 4 and 5, namely:

1. Banks that are included in the Commercial Bank Business Activity (BOOK) group 3 include subsidiaries owned and / or controlled by the bank concerned, and apply individually or on a consolidated basis.

2. Banks that are included in the Commercial Bank Business Activities (BOOK) group 4 include subsidiaries owned and / or controlled by the bank concerned, and apply individually or on a consolidated basis.

3. All Foreign Banks operating in Indonesia, including subsidiaries in Indonesia, which are owned and / or controlled by the bank concerned, and apply individually or on a consolidated basis.

\section{Research and methodology}

This study uses descriptive and verification research methods, the definition of descriptive methods by Wijaya (2019) is a method used to describe or analyze a research result but is not used to make broader conclusions.

\section{Population and sample}

In this study the population determined are companies from the bank sub-sector included in the category of Commercial Banks Based on Business Activities (BOOK) 3 in the 2017-2018 period. The sampling method in this study uses purporsive sampling, Purposive samplings one of the non-random sampling technique where the researcher determines the sampling by determining specific characteristics in accordance with the objectives of the study so that it is expected to answer the research problem, based on the overall population of companies in the bank sub-sector there are 115 companies, which are then re-selected according to the specified sample determination criteria. The research sample was selected from 19 companies based on predetermined criteria. so that a total of 76 units of observation.

\section{Types and data sources}

The type of data used in this study is a type of secondary data. The data used in this study was obtained from the website www.idx.co.id.

\section{Data collection technique}

Data collection techniques conducted by the authors in this study are Library Research and Internet Research.

\section{Data analysis method}

Data analysis technique Analysis of the data used in this study is panel data regression using the application program Eviews 9. Before panel data regression analysis, the model selection and classical assumption test are performed using heteroscedasticity and multicollinearity tests. Panel data analysis is used to answer hypothesis testing regarding the effect of independent variables on the dependent variable. The research panel data regression model is as follows (Wijaya, 2019):

$\mathrm{Y}=\mathrm{a}+\mathrm{b}_{1} \mathrm{x}_{1}++\mathrm{b}_{2} \mathrm{x}_{2}+\mathrm{e}$

interpretation : 


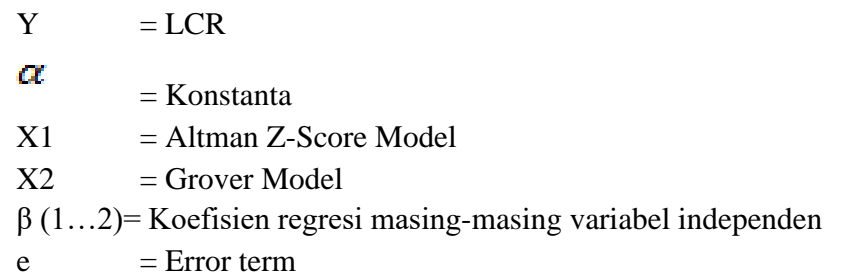

\section{Hypothesis testing}

1. In this study the test method against the proposed hypothesis is carried out $t$ test and model test and analysis of the coefficient of determination (R2).

2. T test is used to determine whether the independent variable regression model (X) individually has a significant effect on the dependent variable (Y).

3. Model Test / Test F is used to test whether the regression model that is made is right / significant or inappropriate / non significant.

4. The coefficient of determination (R2) is used to measure the extent of the ability of the model to explain the variation of the dependent variable

\section{Result and discussion}

\section{Data}

In this study, the unit of analysis is the company's sub-sector banks included in the category of Commercial Banks Based Operations (BOOK) 3 in the period 2017-2018. Based on the overall population of companies in the sub-sector banks there are 115 companies which is a sub-sector bank and operates in the period from 2017 to 2018, selected samples are 19 companies based on predetermined criteria Data in this study has a number of time series data as much as 4 period and the data as much as 19 cross-sectional data, crosssectional data were carefully selected from the existing population.

\section{Descriptive statistics}

Descriptive statistical analysis describing the character of the sample used in this study. Descriptive analysis of data taken for this research were 76 observational data. Description of the variables used in the study include the minimum, maximum, mean and standard deviation of the dependent variable is the LCR and the two independent variables are Altman and Grover. The descriptive statistics output are shown in Table 2.

\section{LCR}

The calculated mean value of the LCR variable is 195.8899 , the middle value of the LCR variable is 156.8450 , the maximum value of the LCR variable is 628.4 obtained by PT. Bank ANZ Indonesia in 2017 quarter 3, the minimum value of the LCR variable was 94.22 obtained by PT. Bank ICBC Indonesia in 2018 quarter 1, and the value of the standard deviation of the LCR variable is 101,9919. slope of data distribution (the amount of data sharing or the average distribution of data which is usually manifested in the form of a bell, for normally distributed data) the LCR variable is 2.431401, the data distribution fluctuation (The taper value of kurtosis will show almost homogeneous data) of 9.213107 , the number of samples used was 76 data.

Table 2: Descriptive statistics output

\begin{tabular}{llll}
\hline & LCR & Altman & Grover \\
\hline Mean & 195.8899 & 2.032365 & 0.525710 \\
\hline Median & 156.8450 & 1.778976 & 0.485508 \\
\hline Maximum & 628.4000 & 4.281294 & 1.080187 \\
\hline Minimum & 94.22000 & 0.479908 & 0.182044 \\
\hline Std. Dev. & 101.9919 & 0.940398 & 0.201531 \\
\hline Skewness & 2.431401 & 0.906483 & 1.014536 \\
\hline Kurtosis & 9.213107 & 2.874640 & 3.479815 \\
\hline Jarque-Bera & 19.12735 & 10.45812 & 13.76662 \\
\hline Probability & 4.523390 & 9.715359 & 7.181025 \\
\hline Sum & 14887.63 & 154.4597 & 39.95393 \\
\hline Sum Sq. Dev. & 780175.5 & 66.32614 & 3.046107 \\
\hline Observations & 76 & 76 & 76 \\
\hline
\end{tabular}




\begin{abstract}
Altman
The calculated average value of the Altman variable is 2.032365, the middle value of the Altman variable is 1.778976, the maximum value of the Altman variable is 4.281294 obtained by PT. Bank Sumitomo Mitsui Indonesia in 2018 quarter 2, the minimum value of the Altman variable of 0.479908 obtained by PT. Bank Bukopin Tbk in 2018 quarter 1, and the value of the standard deviation of the LCR variable is 0.940398 . slope of data distribution (the amount of data sharing or the average distribution of data which is usually manifested in the form of a bell, for data that is normally distributed) Altman variable of 0.906483 , the data distribution fluctuation (The more pointed the kurtosis value will show almost homogeneous data) of 2.874640 , the number of samples used was 76 data.
\end{abstract}

\title{
Grover
}

The calculated average value of the Grover variable is 0.525710 , the middle value of the Grover variable is 0.485508 , the maximum value of the Grover variable is 1.080187 obtained by PT. Bank Sumitomo Mitsui Indonesia in 2018 quarter 2, the minimum value of the Grover variable of 0.182044 obtained by PT. Bank Bukopin Tbk in 2018 quarter 1, and the value of the standard deviation of the Grover variable is 0.201531 . the slope of the data distribution (the magnitude of data sharing or the average distribution of data which is usually manifested in the form of a bell, for normally distributed data) the Grover variable is 1.014536, the data distribution fluctuation (The tapering of the kurtosis value will show nearly homogeneous data) of 3.479815, the number of samples used was 76 data.

\section{Classic assumption test}

Normality test

Normality test is intended to determine whether residual regression models examined distribute normal or not. normality test data using the Jarque-Bera test. If prob. Jarque-Bera is more than 0.05, it can be concluded that data are normally distributed. Conversely, when the prob. Jarque-Bera less than 0.05 then it indicates that the data were not normally distributed. Figure 1 show the value prob. Jarque-Bera amounted to $5.718423>0.05$ indicating that data is normally distributed.

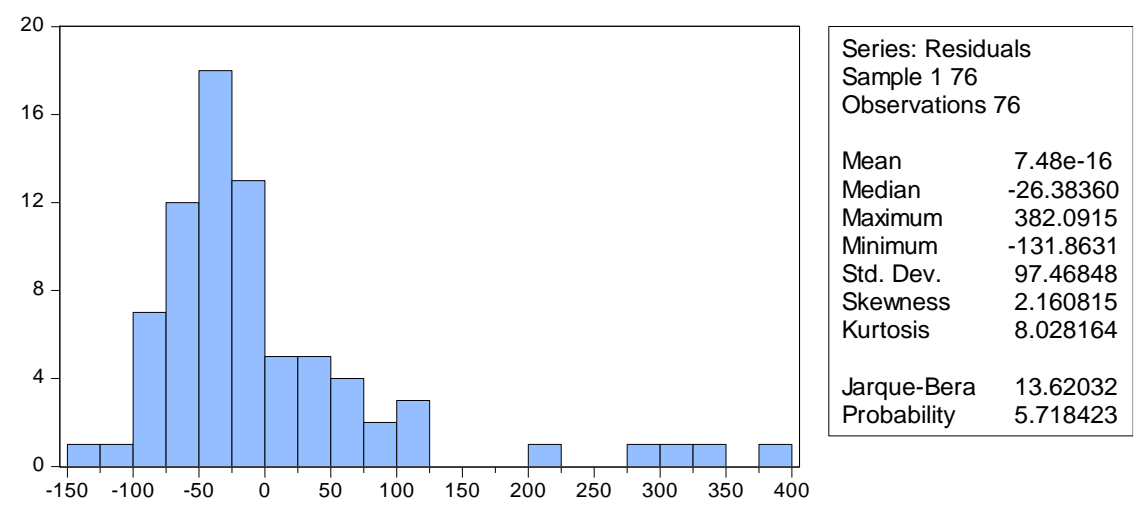

Fig. 1: Normality test output

\section{Autocorrelation test}

Autocorrelation test was conducted to test whether there is a correlation between the regression model in period t disturber error with error period t-1 (previous). Autocorrelation test conducted by the Durbin-Watson test (See Table 3).

Table 3: Autocorrelation Test output

\begin{tabular}{llll}
\hline R-squared & $\mathbf{0 . 0 8 6 7 3 4}$ & Mean dependent VAR & $\mathbf{1 9 5 . 8 8 9 9}$ \\
\hline Adjusted R-squared & 0.061713 & SD dependent var & 101.9919 \\
\hline SE of regression & 98.79464 & Akaike information criterion & 12.06264 \\
\hline Sum squared resid & 712507.8 & Schwarz criterion & 12.15464 \\
\hline Log likelihood & -455.3802 & Hannan-Quinn criter. & 12.09941 \\
\hline F-statistic & 3.466448 & Durbin-Watson stat & 1.652773 \\
\hline Prob (F-statistic) & 0.036459 & & \\
\hline
\end{tabular}


Table 3 show the Durbin-Watson amounted to 1.652773, the value will be compared with the table of the Durbin-Watson with the number of observations $(n)=76$, the number of independent variables $(k)=2$ and a significant level of 0:05 so that the value of the Durbin-Watson table is as follows :

$(\mathrm{N})=76$

$(\mathrm{K})=2$

$\alpha=0: 05$

obtained:

$\mathrm{dL}=1.5740$

$\mathrm{dU}=1.6819$

calculation:

$\mathrm{dL}=1.5740$

$\mathrm{dU}=1.6819$

$\mathrm{dW}=1.652773$

4-dU $=2.3181$

$4-\mathrm{dL}=2,426$

When compared between the Durbin-Watson calculated with Durbin-Watson table shows that the value of dU (1.6819)> dW (1.652773) <4-dU (2.3181) which means that there are symptoms of autocorrelation.

\section{Multicollinearity test}

Multicollinearitas aims to test whether the regression model found a correlation between independent variables (independent). A good regression model should not happen correlation between independent variables. If the independent variables are correlated, then these variables are not orthogonal (See Table 4). Orthogonal variable is the independent variable correlation value between the members of the independent variables equal to zero. Multicolinearity test in this study by looking at the value of Variance Inflation Factor (VIF).

Table 4: Multicollinearity Test Output

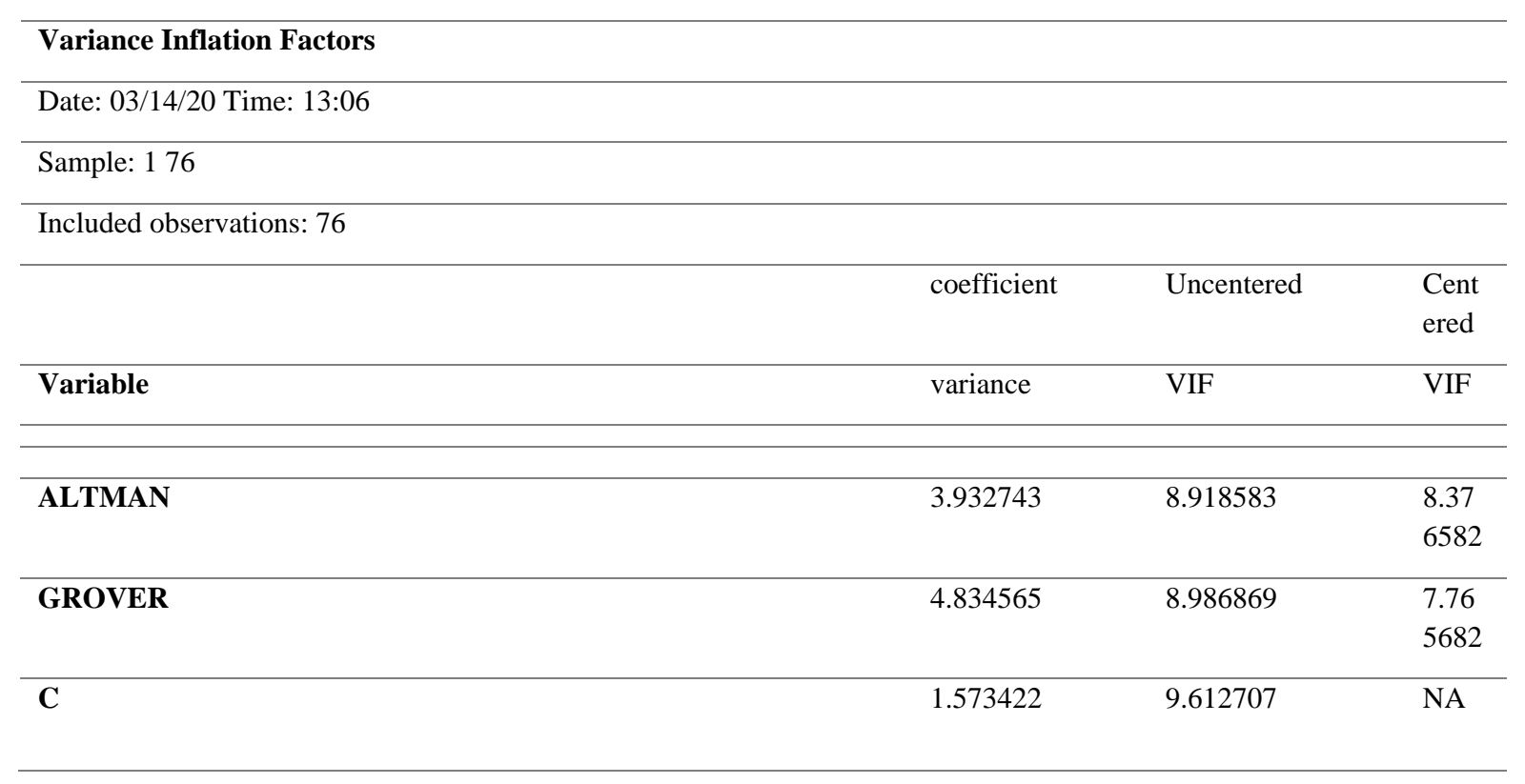

Value Centered Variance Inflation Factor (VIF) is smaller than the critical value set (VIF <10), thus the regression model in this study did not happen multicollinearity between independent variables or it can be said that all independent variables in the regression model of this research has been mutually independent and dipenelitian regression model is fit for use.

\section{Heteroskedasticity test}

This test aims to test whether the regression model occurred inequality residual variance from one observation to another observation. If the residual variance of an observation to observation of the other fixed, then called homokedastisitas, and if different is called heterokedastisitas. Heterokedastisitas test in this research is done by using test Breusch Pagan Godfrey. 
Table 5: Normality Test Output

\begin{tabular}{lclc}
\hline Heteroskedasticity Test: Breusch-Pagan-Godfrey & & \\
\hline F-statistic & 2.138648 & Prob. F (4,200) & 0.1251 \\
\hline Obs * R-squared & 4.206598 & Prob. Chi-Square (4) & 0.1221 \\
\hline Scaled explained SS & 13.63834 & Prob. Chi-Square (4) & 0.0011
\end{tabular}

Indicates that the prob. Chi Square of $0.1221>0.05$ thus it can be concluded that the regression model proposed in this study there was no trouble heteroskedastisity (data meet the assumptions homokedastisitas) in the regression equation (See Table 5).

\section{Selection of panel data regression model}

Selection of this estimation model to determine the model of the common effect, fixed effect and random effect estimation model used three techniques. Three techniques are used in panel data regression to obtain the right model in estimating panel data regression.

Chow Test

Chow test results based on the cross section of Chi-Square sebesaar 0000. Due to the probability value is smaller than the specified significance level $(0.0000<0.05)$, then the fixed effect model is more appropriate model than the common effect (See Table 6).

Table 6: Chow test output

\begin{tabular}{llll}
\hline Fixed Effect redudant Teats & & & \\
\hline Equation: Untitled & & & \\
\hline Test cross-section fixed effect & statistics & $\mathrm{df}$ & Prob. \\
\hline Effects Test & 12.316159 & $(18.55)$ & 0.0000 \\
\hline Cross-section F & 122.783145 & 18 & 0.0000 \\
\hline Cross-section Chi-square & & & 18 \\
\hline
\end{tabular}

\section{Lagrange Multiplier (LM) Test}

Results Lagrange Multiplier based on the statistical prob. Breusch-Pagan at 0.0000 The smaller value of alpha 0.05 so that $\mathrm{H} 0$ rejected and $\mathrm{H} 1$ be accepted. This means that random effect models are more appropriate model than the common effect (See Table 7).

Table 7: Lagrange multiplier test output

\begin{tabular}{llll}
\hline \multicolumn{2}{l}{ Lagrange multiplier (LM) test for Random Effects } & \\
\hline Null (no rand. Effect) & Cross-section & Hypothesis Test & Both \\
\hline alternative & & time & 39.75550 \\
\hline Breusch-Pagan & 39.51486 & 0.240642 & $(0.0000)$
\end{tabular}

\section{Hausman Test}

Value statistics probability random cross section of 0.0005 Due probability value smaller than the specified significance level $(0.0005$ $<0.05$ ), then $\mathrm{H} 0$ is rejected and $\mathrm{H} 1$ be accepted. This means that teapat Fixed Effect Model is used (See Table 8). Based on the above results it can be concluded in this study using a test election of the fixed effect model. Results of Fixed Effect Model.

Table 8: Hausman test output

\begin{tabular}{llll}
\hline Correlated Random Effect - Hausman Test & & \\
\hline Equation: Untitled & & & \\
\hline Test cross-section random effect & & Chi-Sq. df & Prob. \\
\hline Test Summary & Chi-Sq. statistics & 2 & 0.0005 \\
\hline Cross-section Random & 15.064902 & & \\
\hline
\end{tabular}




\section{Results of panel data regression model}

After doing 3 tests namely chow test, Hausman test and lagrange multiplier test, it can be concluded that the fixed effect is the best models for Estimating the parameters of the data panel regression models. the regression models in this study is as follows:

$\mathrm{Y}=339.2645-176.2473+408.6365$ GROVER ALTMAN

The interpretation of the results of the regression analysis above are as follows:

1. Constant value obtained at 339.2645. This means that if Altman and Grover fixed or no increase or reduction (zero value), then the LCR at a constant value is 339.2645 .

2. Altman coefficient value of - 176.2473. This implies that each increase of 1unit Altman, it will lower the LCR at 176.2473.

3. Grover coefficient value of 408.6365. This implies that any increase in Grover by 1 unit, then it will increase the LCR at 408.6365 .

Table 9: Fixed effect model output

\begin{tabular}{lllll}
\hline Variable & coefficient & Std. Error & t-Statistic & Prob. \\
\hline ALTMAN & -176.2473 & 53.90106 & -3.269829 & 0.0019 \\
\hline GROVER & 408.6365 & 187.6529 & 2.177619 & 0.0337 \\
\hline C & 339.2645 & 56.56506 & 5.997774 & 0.0000 \\
\hline Adjusted R-square & & & & \\
\hline Prob (F-statistic) & 0.752450 & & & \\
\cline { 2 - 4 } & 0.000000 & & & \\
\hline
\end{tabular}

Based on Table 9, $\mathrm{t}$ probability statistics on Altman variable of 0.0019 . That is leverage significant effect on the LCR due to the probability of $\mathrm{t}$ statistic (0.0019) < alpha (0:05). This shows that the level of banking affects Altman's health coverage ratio of liquidity in the corporate banking sub-sector included in the category of commercial banks based on business activities (BOOK) 3.t probability statistics on Grover variable of 0.0337 . That is leverage significant effect on the LCR due to the probability of $\mathrm{t}$ statistic $(0.0337)<$ alpha (0:05). This shows that the level of banking affects the Grover health coverage ratio of liquidity in the corporate banking subsector which is included in the category of commercial banks based on business activities (BOOK) 3 .

According to the table above illustrates that the independent variables used in this research is able to explain the dependent variable fine or regression model used was appropriate. Value prob. F-statistic is equal to $0.000000>0.05$, it can be concluded that the variable Altman and Grover have a linear relationship with variable LCR or regression model used was appropriate.The result of the coefficient of determination in the above table shows the adjusted R-square of 0.752450 , which means that the ability of independent variables (Altman and Grover) in explaining the variation in the dependent variable (LCR) amounted to 75.25\%, while the remaining $24.75 \%$ influenced by other variables that are not used in this study (See Table 9).

\section{Conclusions}

Based on the discussion, it can be seen that health with the Altman Z-Score modification method from the effect on the Liquidity Coverage Ratio, the level of health with the Grover method of influence on Liquidity Coverage Ratio. From these conclusions and the results of research conducted, it can be seen that the application of the Liquidity Coverage Ratio has not been able to have an impact in accordance with its main objective, namely to increase liquidity capacity and reduce liquidity risk in banks, especially those included in the BOOK 3 category. This seems to be one of the sectors Vulnerable banks included in BOOK 3 to experience a level of health below the standards set by government policy, supported by a high level of LDR, would be normal if the soundness of the banking system would affect the level of Liquidity Coverage Ratio. this is in line with what happened in several other economically established countries such as Hong Kong, Jamaica, Australia and even some countries in Europe.

\section{References}

Altman, E. I., \& Hotchkiss, E., (2006). Corporate Financial Distress and Bankruptcy. New Jersey: John Wiley \& Sons, Inc.

Authority, H. K. (2013). Implementation of Basel III Liquidity Standards in Hong Kong (L3). Hong Kong: Retrieved from www.hkma.gov.hk.

Duijm, P., \& Wierts, P. (2016). The effects of liquidity regulation on bank assets and liabilities. International Journal of Central Banking, 1-24.

Edi, E., \& Tania, M. (2018). Ketepatan Model Altman, Springate, Zmijewski, dan Grover dalam Memprediksi Financial Distress. Jurnal Reviu Akuntansi dan Keuangan, 8(1), 79-92. https://doi.org/10.22219/jrak.v8i1.28 
Grummit, N. (2013). Implementing Basel III liquidity reforms. Sydney: Australian Prudential Regulation Authority.

Hoerova, M., Mendicino, C., Nikolov, K., Schepens, G., \& Van den Heuvel, S (2018). Benefits and costs of liquidity regulation. ECB Working Paper Series, 2169, 1-67.

Hermina, R., \& Suprianto, E. (2014). Analysis of the Influence of Car, Npl, Ldr, and Bopo Against. Indonesian Accounting Journal, 129-142.

Jamaica, T. B. (2019, June). The Liquidity Coverage Ratio. Kingston: www.boj.org.jm

Kurniawan, R., \& Managi, S. (2018). Economic growth and sustainable development in Indonesia: an assessment. Bulletin of Indonesian Economic Studies, 54(3), 339-361. https://doi.org/10.1080/00074918.2018.1450962

Raz, A. (2013). The nexus between bank credit development and economic growth in Indonesia. DLSU Business \& Economics Review, 23(1), 93-104.

Shahbaz, M., Hye, Q. M. A., Tiwari, A. K., \& Leitão, N. C. (2013). Economic growth, energy consumption, financial development, international trade and $\mathrm{CO} 2$ emissions in Indonesia. Renewable and Sustainable Energy Reviews, 25, 109-121. https://doi.org/10.1016/j.rser.2013.04.009

Supartoyo, Y. H., Tatuh, J., \& Sendouw, R. H. (2013). the economic growth and the regional characteristics: the case of indonesia. Buletin Ekonomi Moneter dan Perbankan, 16(1), 3-18. https://doi.org/10.21098/bemp.v16i1.435

Undang-undang No. 10 Tahun 1998. About Banking

Wijaya, J. H. (2019). The Effect of Leverage and Good Corporate Governance on Profitability in Banking Companies Listed in Indonesia Stock Exchange in The 2014-2016 Period . JARDCS, 11(3), 684-688. 